УДК 364.05

Купира М.І., к.е.н., ст.викладач

Луцький національний технічний університет

\title{
ПРАКТИЧНІ АСПЕКТИ ФІНАНСОВОГО ЗАБЕЗПЕЧЕННЯ СОЦІАЛЬНОГО ЗАХИСТУ НАСЕЛЕННЯ
}

\begin{abstract}
У статті обгрунтовано сутність соціального захисту з виділенням характерних особливостей даного поняття. Розроблено системну структуру політики соціального захисту за рівнями, цілями, завданнями в процесі фінансового забезпечення. Проаналізовано заходи соціального характеру, на які передбачено виділення коштів із державного бюджету. Подано напрямки реформування системи соціального захисту в напрямку фінансового забезпечення, з використанням досвіду розвинутих країн., обгрунтовано необхідні умови реформування та ключові аспекти розвитку соціального захисту для України.
\end{abstract}

Ключові слова: соціальний захист, фінансове забезпечення, видатки, доходи, модернізація.

Купира М.И.

\section{ПРАКТИЧЕСКИЕ АСПЕКТЫ ФИНАНСОВОГО ОБЕСПЕЧЕНИЯ СОЩИАЛЬНОЙ ЗАЩИТЫ НАСЕЛЕНИЯ}

В статье обосновано сущность социальной защиты с выделением характерных особенностей данного понятия. Разработана системная структура политики социальной защиты по уровням, целями, задачами в процессе финансового обеспечения. Проанализированы меры социального характера, на которые предусмотрено выделение средств из государственного бюджета. Подано направления реформирования системы социальной защиты в направлении финансового обеспечения, с использованием опыта развитых стран. Обоснованно необходимые условия реформирования и ключевые аспекты развития социальной защиты Украины.

Ключевые слова: социальная защита, финансовое обеспечение, держава, расходы, доходы, модернизация.

Kupyra M.

\section{PRACTICAL ASPECTS THE FINANCIAL PROVIDING SOCIAL PROTECTION OF POPULATION} concept.

In the article essence of social protection is reasonable with theselection of characteristic features of this

The system structure of politics of social protection is workedout after levels, aims, tasks in the process of the financial providing. The measures of social character, on that the provision of funds from the state budget, are analysed. Directions of reformation the system of social protection are given in direction of the financial providing, with the use of experience developed countries, necessary terms of reformation and key aspects of development social protection are reasonable for Ukraine.

Key words: social protection, financial providing, expenses, revenues, modernization.

Постановка проблеми у загальному вигляді i iï зв'язок 3 важливими науковими та практичними завданнями. В Україні діяльність держави 3 приводу фінансування соціальної сфери є досить суперечливим питанням, що зумовлено високим рівнем інфляції в напрямку різкого падіння доходів переважної більшості населення в умовах соціально-економічних дисбалансів. Відтак, традиційним виступає налаштованість громадян на отримання різного роду соціальних послуг від держави, що свідчить про низьку ефективність економічної і соціальної політики. В цьому контексті і виникають проблеми з фінансуванням соціальної сфери. Відтак, аналіз та пошук шляхів фінансового забезпечення соціального захисту $є$ одним 3 найважливіших аспектів діяльності держави. Тобто, створити сприятливі умови для безперервності 
відтворювального процесу в напрямку системної фінансової політики соціального захисту населення.

Аналіз останніх досліджень, у яких започаткованог вирішення проблеми. Питання соціального захисту та соціального забезпечення завжди цікавили науковців. Дослідженням сутності соціального захисту в теоретичному і практичному аспектах, питаннями політики соціального захисту та фінансового забезпечення даного напрямку займалися вітчизняні та зарубіжні вчені, серед яких найбільшою обгрунтованістю вирізняються наукові праці: Флорескул Н., Грушко В.І., Гриненко А.М., Бендасюк О., Мельник К.Ю., Мальоничий М.І., Борецька Н.П., Скуратівський В.А.. Однак, дослідження економічної сутності соціального захисту акумулює в собі різні трактування, що не мають єдиного бачення та потребують детального вивчення в напрямку ефективного його фінансового забезпечення .

Цілі статті. Полягають в обгрунтування сутності соціального захисту та напрямків його фінансового забезпечення.

Виклад основного матеріалу дослідження 3 повним обгрунтуванням отриманих нгаукових результатів. Соціальний захист населення України є одним із найважливіших показників розвитку, фінансового забезпечення та функціонування держави. Вважається, що забезпечення соціального захисту громадян повинна надавати держава на чолі зі своїм керівництвом. Однак, в нашій країні дане питання носить суперечливий характер, так як державне фінансування соціальної сфери потребує перегляду на законодавчому рівні в напрямку використання іноземного досвіду.

Питання теоретичного аспекту визначення поняття «соціальний захист» відображені у багатьох наукових працях, що висвітлюють різні погляди на його суть. 3 метою формування суті соціального захисту охарактеризовано категорію через функцію, комплекс заходів і дій, систему та політику держави.

В результаті дослідження сутності соціального захисту виділено характерні особливості даного поняття:

1) категорія;

2) вивчення з інституційної точки зору;

3) використання системного підходу в напрямку оцінки та аналізу;

4) дослідження через призму соціальних інститутів та інституцій.

Відтак, під соціальним захистом будемо розуміти комплексну систему заходів держави в напрямку фінансового забезпечення населення та формування безпечного середовища для життя та розвитку кожної людини.

Дослідження сутності та змісту поняття соціального захисту зумовлює потребу у структуруванні суб'єктів (державні структури, органи місцевого самоврядування, громадські організації та фонди, союзи й асоціації підприємців), об'єктів (населення), рівнів, цілей, функцій та форм, що є важливими показниками у вивченні проблеми фінансового забезпечення соціального захисту.

На рисунку 1 зображено системну структуру політики соціального захисту за рівнями, цілями та завданнями в процесі фінансового забезпечення.

Отже, в процесі формування та здійснення політики соціального захисту населення виконується ряд функцій, що в комплексі забезпечують реалізацію поставлених цілей та завдань, серед яких основними є: загальні, спеціальні та допоміжні.

В процесі дослідження дотримуємось думки щодо важливості загальних функцій, які спрямовані на забезпечення розвитку населення в цілому, регулювання суспільних відносин у сфері розподілу і перерозподілу матеріальних благ та фінансових ресурсів, попередження виникнення негативних процесів і явищ у суспільстві.

Сьогодні пріоритетними завданнями у сфері соціального захисту є підвищення ефективності управління бюджетними коштами для державної підтримки соціально 
бідних верств населення, подальше реформування сфери надання соціальних послуг і соціального захисту [1]

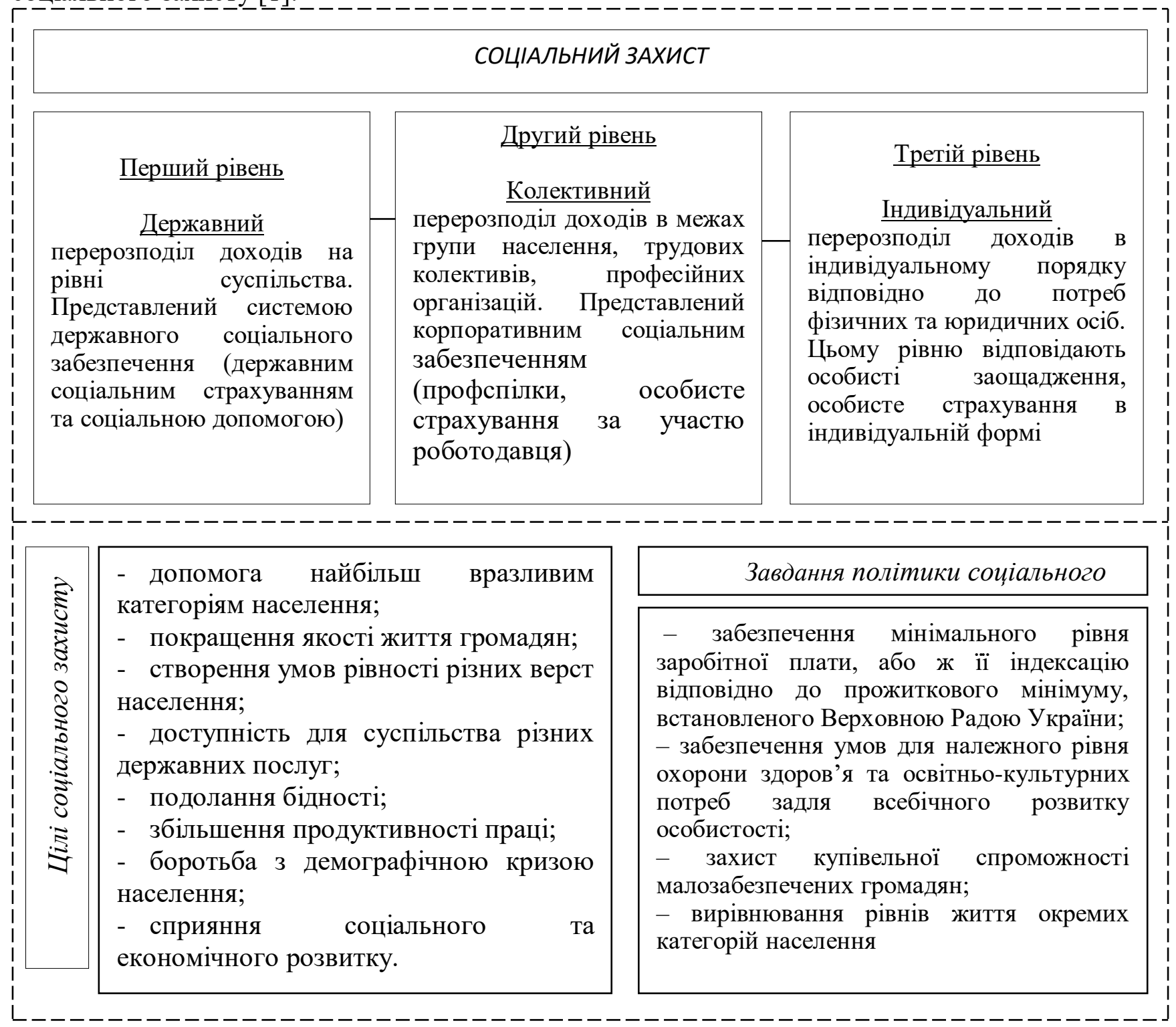

Рис. 1. Системна структура політики соціального захисту

Отже, загальний ресурс місцевих бюджетів на 2019 рік становить 588,9 млрд грн, в тому числі [2]:

-власні доходи місцевих бюджетів (із них реверсна дотація - 6,8 млрд грн) складають - 291,1 млрд. грн, що більше на 16,6 \% у порівнянні із затвердженими місцевими бюджетами на 2018 рік, та більше від очікуваних надходжень на 12,5 \%), із них:

загальний фонд становить 265,7 млрд. грн (збільшується на 16,9 \% порівняно із затвердженими обсягами);

спецііальний фонд - 25,5 млрд грн збільшується на 13,5 \%;

-трансферти 3 державного бюджету становитимуть 304,6 млрд грн.

Розмір субвенцій $з$ державного бюджету місцевим бюджетам передбачено в загальній сумі 257,3 млрд грн, зокрема:

-субвенція на здійснення державних програм соціального захисту населення 122,0 млрд грн: 3 них на: виплату допомоги сім'ям 3 дітьми, малозабезпеченим сім 'ям, 
особам - 63,0 млрд грн; надання пільг та житлових субсидій населенню на енергоносії 55,1 млрд грн; надання пільг та житлових субсидій населенню на придбання твердого та рідкого пічного побутового палива і скрапленого газу - 2,9 млрд грн; виплату державної соціальної допомоги на дітей-сиріт - 997,1 млн грн;

-освітня субвенція - 71,0 млрд грн (15,1 \% більше порівняно з 2018 роком, у 2018 p. $-61,7$ млрд грн).

Усього Міністерство соціальної політики України в держбюджеті на 2017 p. виділило 88,659 млрд грн. Пенсійний фонд із цієї суми становить 83,233 млрд грн. Це на 18,7 млрд грн (або на 29 \%) більше, ніж у 2016 р.. У бюджеті на 2019 р. передбачено вирішення низки питань соціального характеру проти показників 2018 р. (табл. 1).

Табдиця 1

Заходи соціального характеру, на які передбачено виділення коштів із державного бюджету у 2017-2019 роках, \%

\begin{tabular}{|c|c|c|c|}
\hline \multirow[t]{2}{*}{ Питання соціального характеру } & \multicolumn{3}{|c|}{ Кошти, які передбачено виділити, млрд грн / \% } \\
\hline & 2017 & 2018 & 2019 \\
\hline $\begin{array}{l}\text { Збільшення допомоги малозабезпеченим } \\
\text { сім'ям, інвалідам } 3 \text { дитинства і дітям-інвалідам } \\
\text { та допомоги на догляд за інвалідом I чи II групи }\end{array}$ & $\begin{array}{c}53,9 \\
\text { млрд грн }\end{array}$ & $\begin{array}{c}59,9 \\
\text { млрд грн }\end{array}$ & 63,0 млрд грн \\
\hline Збільшення мінімальної заробітної плати & на $8,7 \%$ & на $14,0 \%$ & на $10,8 \%$ \\
\hline прожиткового мінімуму для працюючих осіб & на $9,2 \%$ & на $8,3 \%$ & на $5,2 \%$ \\
\hline $\begin{array}{l}\text { Збільшення (зменшення) субвенції } \\
\text { соціальний захист }\end{array}$ & $\begin{array}{c}\text { на } 24,1 \% \\
124,7 \text { млрд.грн. }\end{array}$ & $\begin{array}{c}\text { на } 0,5 \% \\
125,3 \text { млрд.грн. }\end{array}$ & $\begin{array}{c}\text { на }-2,7 \% \\
122 \text { млрд.грн. }\end{array}$ \\
\hline
\end{tabular}

Переглянувши таблицю, ми можемо сказати, що держава планує підвищити рівень життя населення, проте чи результатні будуть такі дії покаже час. Незважаючи на значні розміри соціальних видатків, багато соціальних програм та допомог в Україні фінансується вкрай незадовільно. Окремі види соціальних допомог у деякі роки зовсім не фінансувалися або їхні розміри у законодавчому порядку зменшувалися, оскільки у Державному бюджеті України на це не вистачало коштів. Проаналізуємо структуру видатків Державного бюджету на соціальний захист та соціальне забезпечення у 20152017 роках (рис. 2)

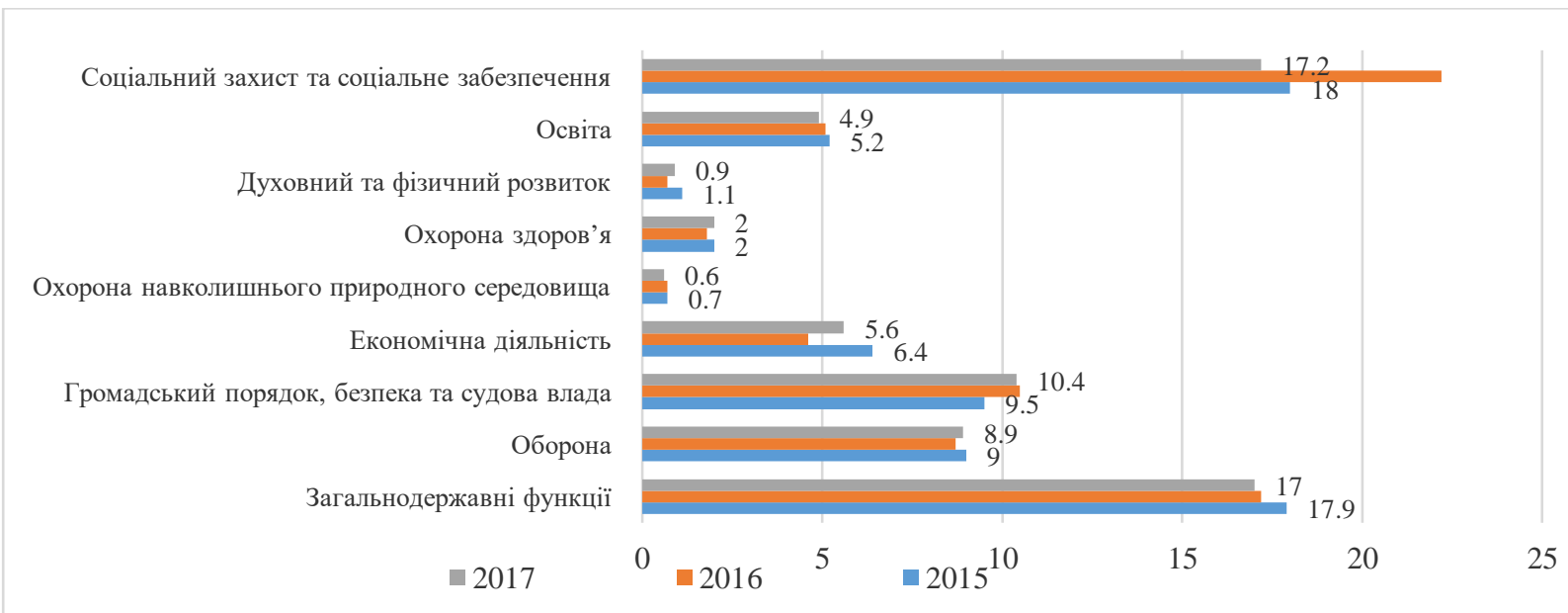

Рис. 2. Динаміка фінансування соціального захисту у структурі видатків Державного бюджету України у 2015-2017 роках [3]

Проведений аналіз свідчить про те, що всі розглянуті програми соціальної підтримки мали помітний вплив на рівень бідності одержувачів допомоги. При цьому найбільший вплив мала програма житлових субсидій, незважаючи на низький рівень іiі 
адресності: рівень абсолютної бідності серед учасників програми знизився на 12,9 \%. Значний вплив на рівень бідності (зменшення на 8,4 \%) також мала допомога малозабезпеченим сім'ям та допомога одиноким батькам, що свідчить про кращу націленість програм на бідне населення та важливість виплат для їх учасників. Допомога при народженні дитини також дозволила покращити рівень життя серед їі одержувачів, де рівень бідності за абсолютним критерієм знизився на 7,6\%.

Значною проблемою у фінансовому забезпеченні соціального захисту $є$ те, що значна частина фінансових ресурсів спрямовується на підтримку населення, яке не потребує такої допомоги, що негативним чином позначається на рівні життя найменш захищених верств населення. Крім цього, для національної системи соціального захисту характерним $€$ наявність великої кількості натуральних трансфертів, частка яких складає близько $13 \%$.

Таким чином, модернізація соціального захисту є вкрай важливою в системі євроінтеграційних викликів. Зміни забезпечать зменшення видатків державного бюджету та покращать добробут незахищених верств населення, в напрямку забезпечення достойного рівня життя (табл. 2). Адже, соціальна реформа має мати на меті створення нової моделі соціального забезпечення громадян України, яка здатна забезпечити мінімально належний соціальний захист населення за простою формулою, водночас 3 ефективним соціально-економічним розвитком, створити стимули для саморозвитку, відтворення та розвитку здорової української нації.

Необхідними передумовами проведення ефективної соціальної реформи $\epsilon$ забезпечення ефективної взаємодії між громадянами та органами влади та місцевого самоврядування, забезпечення максимальної прозорості на усіх рівнях та напрямках. Тобто стратегія соціально-економічного розвитку України передбачає створення умов для прискорення євроінтеграційних процесів шляхом масштабного впровадження загальноєвропейських норм і стандартів до законодавства та системи державного управління.

Модернізацію системи соціального захисту доцільно проводити в напрямку зростання в ній частки страхових відносин, які відповідають ринковим соціальноекономічним умовам та забезпечують розподіл матеріальної відповідальності щодо компенсації та мінімізації соціальних ризиків на максимальну можливу кількість учасників, посилити адресність соціальної допомоги і підвищити ефективність їі використання; більшою мірою залучати громадські організації до соціального захисту окремих категорій населення.

Існуючий ряд чинників не дозволяють швидко змінити напрацьовану соціальну інфраструктуру, що і позначається на майбутніх реформах: низька довіра населення до фінансових установ, негативна демографічна ситуація, відсутність стимулу до нарощення власної фінансової бази, що призводить до додаткових зобов'язань в системі соціального захисту, які нічим не підкріплені та поглиблюють диспропорції в цьому напрямку.

Відтак, окреслені проблеми потребують дієвих кроків в напрямку зменшення асиметрій за рівнем забезпечення соціального захисту без винятку всіх верст населення, перегляд соціальної політики в сторону підвищення фінансової спроможності та забезпечення реалізації цілей та завдань соціального захисту населення власними силами. 
Таблиця 2

Система реформування соціального захисту населення

\begin{tabular}{|c|c|c|c|}
\hline Країна & Характеристика системи соціального захисту & $\begin{array}{c}\text { Необхідні умови реформування } \\
{[5]}\end{array}$ & Ключові аспекти для України \\
\hline 1 & 2 & 3 & 4 \\
\hline Нідерланди & $\begin{array}{l}\text { 1) Соціальна система включає в себе: страхування службовців, } \\
\text { державне страхування та соціальну допомогу; } \\
\text { 2) До соціальної допомоги вдаються у двох випадках: у разі крайньої } \\
\text { необхідності - як до останнього засобу, та коли допомога соціального } \\
\text { страхування менша гарантованого доходу; } \\
\text { 3) П’ять різновидів соціальної допомоги, що фінансуються із загальних } \\
\text { податкових надходжень (допомога дітям, додаткова допомога безробітним і } \\
\text { непрацездатним, допомога за віком і частковою непрацездатністю, } \\
\text { безробітним і тим, хто працює не за договором); } \\
\text { 4) Закон про допомогу інвалідам забезпечує їх життєдіяльність незалежно від } \\
\text { віку та працездатності. }\end{array}$ & $\begin{array}{l}\checkmark \text { створення повноцінних } \\
\text { відкритих реєстрів громадян, } \\
\text { нерухомого майна та землі, і } \\
\text { впровадження персональних } \\
\text { ID-карт; } \\
\checkmark \quad \text { поступовий перехід до } \\
\text { системи виключно } \\
\text { безготівкових стосунків, навіть } \\
\text { у сфері правовідносин між } \\
\text { громадянами; } \\
\checkmark \quad \text { забезпечення } \\
\text { максимальної прозорості } \\
\text { фінансових потоків; } \\
\checkmark \quad \text { відмова від системи } \\
\text { тристороннього соціального } \\
\text { партнерства, сатомість } \\
\text { стимулювання }\end{array}$ & $\begin{array}{l}\text { 1) До соціальної допомоги вдаються у } \\
\text { двох випадках: у разі крайньої } \\
\text { необхідності - як до останнього } \\
\text { засобу, та коли допомога соціального } \\
\text { страхування менша гарантованого } \\
\text { доходу } \\
\text { 2) Соціальна допомога фінансуються із } \\
\text { загальних податкових надходжень } \\
\text { (допомога дітям, додаткова допомога } \\
\text { безробітним і непрацездатним, } \\
\text { допомога за віком і частковою } \\
\text { непрацездатністю, безробітним і тим, } \\
\text { хто працює не за договором); }\end{array}$ \\
\hline Данія & 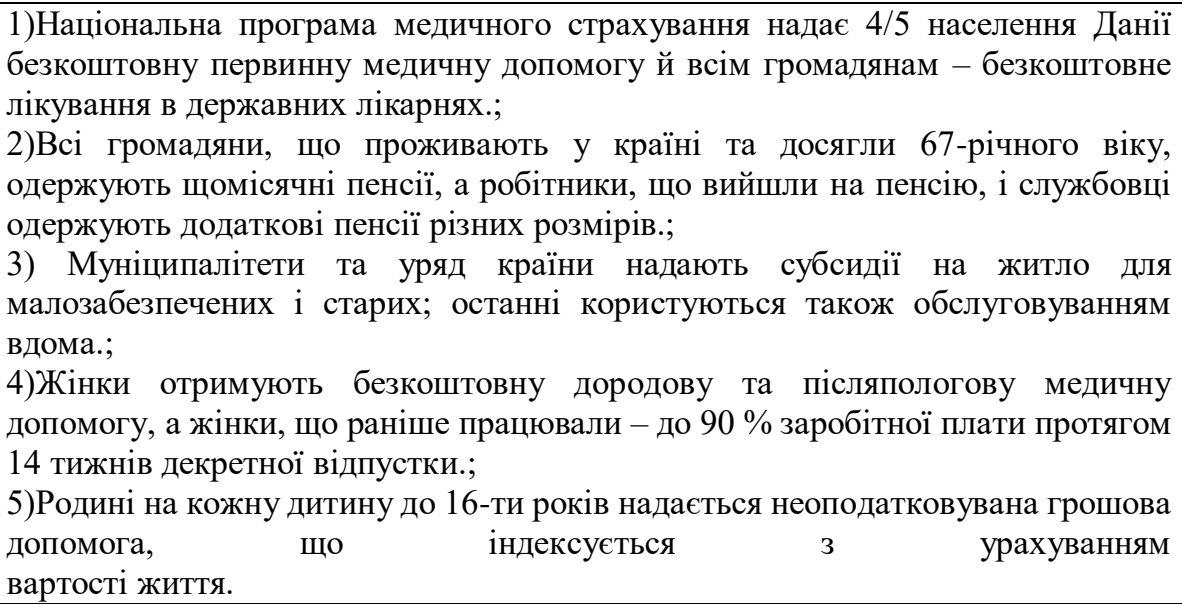 & $\begin{array}{l}\text { двостороннього соціального } \\
\text { партнерства; } \\
\checkmark \quad \text { забезпечення } \\
\text { максимальної прозорості } \\
\text { відносин організацій державної } \\
\text { системи соціального } \\
\text { страхування з громадянами; } \\
\checkmark \quad \text { впровадження системи } \\
\text { обов’язкового } \\
\text { страхування }\end{array}$ & 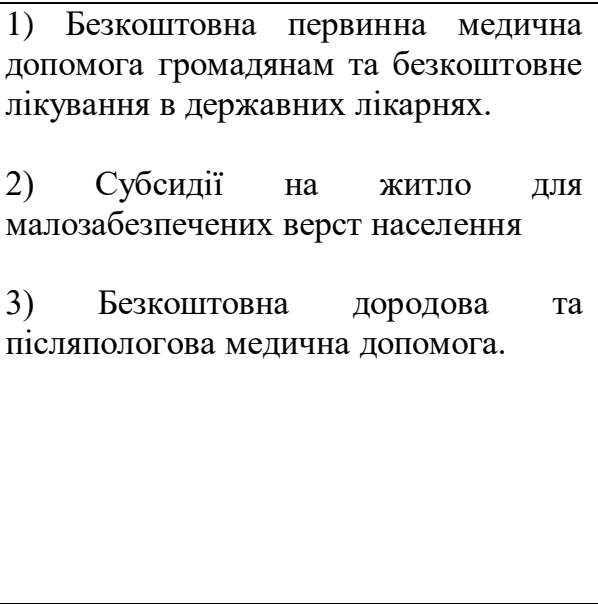 \\
\hline
\end{tabular}


Продовж.. табл. 3

\begin{tabular}{|c|c|c|c|}
\hline 1 & 2 & 3 & 4 \\
\hline Фінляндія & $\begin{array}{l}\text { 1)Соціальне забезпечення, будується за скандинавською моделлю соціальної } \\
\text { держави - всі мають рівні права на одержання тих самих послуг, незалежно від } \\
\text { економічного й соціального статусу; } \\
\text { 2)Існує система обов'язкового страхування по старості й непрацездатності, за } \\
\text { рахунок державних програм виплачуються допомога по безробіттю, допомоги } \\
\text { по вагітності та догляду за дитиною, допомоги багатодітним родинам, } \\
\text { фінансуються дитячі садки й групи продовженого дня в школах, соціальна } \\
\text { допомога інвалідам тощо.; } \\
\text { 3)Інвалідам у Фінляндії надаються такі послуги: курси адаптації та } \\
\text { реабілітаційні консультації, надання житла, особиста допомога й послуги } \\
\text { перекладача для осіб, які погано бачать або чують. Їм відшкодовується вартість } \\
\text { відповідної реконструкції їнього житла, придбаних ними устаткування й } \\
\text { пристосувань, якщо така реконструкція, устаткування або пристосування } \\
\text { необхідні для забезпечення незалежного способу життя інваліда. } \\
\text { Компенсується також вартість медичних послуг і ліків. }\end{array}$ & 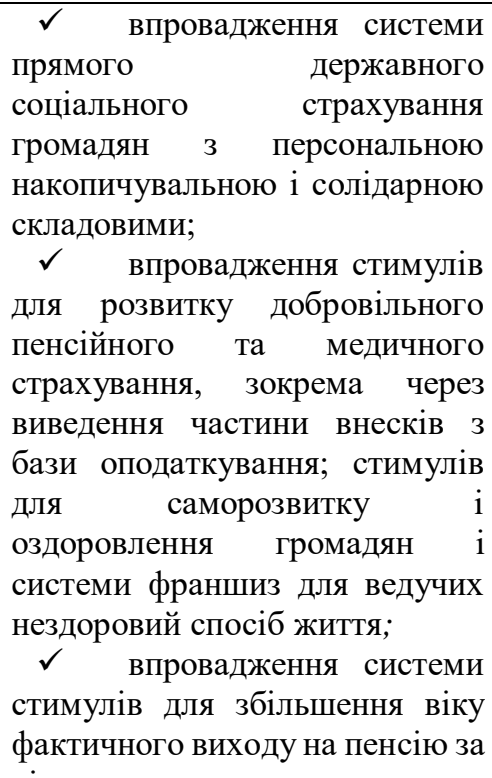 & $\begin{array}{l}\text { 1) Рівні права на одержання соціальних } \\
\text { послуг, незалежно від економічного й } \\
\text { соціального статусу. } \\
\text { 2) Система обов'язкового страхування } \\
\text { по старості й непрацездатності. } \\
\text { 3) Компенсація медичних послуг і ліків } \\
\text { для інвалідів, відшкодування вартості } \\
\text { реконструкції житла, придбаних } \\
\text { устаткування } \quad \text { й } \quad \text { пристосувань } \\
\text { необхідних для } \quad \text { забезпечення } \\
\text { незалежного способу життя }\end{array}$ \\
\hline $\begin{array}{c}\text { Велика } \\
\text { Британія }\end{array}$ & $\begin{array}{l}\text { 1) Британці створили ринок соціальних послуг, який складається з державних, } \\
\text { приватних соціальних служб й громадських організацій, що надають ці } \\
\text { послуги. Таким чином, улюдей є вибір, і в той же час створюється конкуренція } \\
\text { стосовно якості й стандартів послуг між державою та приватними } \\
\text { організаціями.; } \\
\text { 2) В Британії завжди точно знають, яка кількість людей має потребу в } \\
\text { соціальних послугах.; } \\
\text { 3)Стандарти життя дитини в прийомній родині стосуються не тільки умов } \\
\text { проживання, але й, наприклад, таких речей, як право дитини на доступ до } \\
\text { телефону, на спілкування зі своїми біологічними батьками, } \\
\text { якщо вона цього хоче, ще на низку інших, передбачених Конституцією прав. }\end{array}$ & $\begin{array}{l}\text { фактичним збільшенням } \\
\text { пенсійного віку через } \\
\text { застосування франшиз; } \\
\checkmark \text { визначення реального } \\
\text { прожиткового мінімуму та } \\
\text { встановлення мінімальної } \\
\text { пенсії з коефіцієнтом } 1,2 \text { до } \\
\text { цього мінімуму }\end{array}$ & $\begin{array}{l}\text { 1) Створення ринку соціальних } \\
\text { послуг. } \\
\text { 2) Системний моніторинг кількості } \\
\text { людей, що потребують належного } \\
\text { соціально захисту та соціального } \\
\text { забезпечення. } \\
3\end{array}$ \\
\hline
\end{tabular}


Висновки. В такому напрямку державі необхідно чітко формувати цілі, завдання та порядок проведення політики в ключі ефективності, етапи формування та використання фінансових ресурсів, скорочення соціальних допомог та пільг, підвищення адресності, зміни основних умов та принципів фінансування в напрямку збільшення частки приватних коштів, заохочення підприємців до участі в соціальних програмах, встановлення контролю за адресністю соціальних допомог, здійснення перевірки соціальних установ на постійній основі, а також використання досвіду іноземних партнерів. Подібні кроки забезпечуватимуть ефективність реаліхованої політику соціального захисту населення в системі збалансованого фінансового забезпечення.

Отже, реалізація стратегічного курсу на досягнення в Україні європейських стандартів життя має грунтуватися насамперед на радикальному підвищенні якості та ефективності надання послуг соціальної сфери, створення та впровадження правових й організаційних умов недопущення зниження рівня життя населення України.

\section{Список використаних джерел:}

1.Гриненко А. М. Соціальна політика : навч.-метод. посіб. для самостійного вивчення дисципліни. Київ : КНЕУ, 2003. $309 \mathrm{c}$.

2.Інфраструктурна субвенція від держави - скільки отримали волинські ОTГ. URL : https://voladm.gov.ua/new/infrastrukturna-subvenciya-vid-derzhavi-skilki-otrimali-volinski-otg/.

3.Статистичний збірник : «Бюджет України 2017» підготовлено відділом статистики державних фінансів Департаменту державного бюджету Міністерства фінансів України. URL : https://www.minfin.gov.ua/uploads/redactor/files/Budget\%20of\%20Ukraine\%202017\%20(publish).pdf.

4.Що очікує місцеві бюджети у 2019 році. URL : https://decentralization.gov.ua/news/9753.

5.Концепція Громадянської соціальної реформи. URL : http://ukrstrategy.org/uk/projects/37-kontseptsiya-sotsialnojireformi.html.

6.Флорескул Н. Система соціального захисту населення як чинник формування соціальної держави. Вісник КНТЕУ, 2009. №2. С.34-46.

7.Грушко В. І. Пенсійна система України : навч. посіб. К., 2006. 496 с.

8.Бендасюк О. О. Державне управління соціальним захистом населення в умовах ринкової економіки. Галицький економічний вісник. 2010. № 1(26). С. 123-126.

9.Мельник К. Ю. Проблеми соціального захисту працівників органів внутрішніх справ. Право і безпека. 2002. № 2. С. 97-101.

10. Мальований М. І. Фінансові аспекти функціонування системи соціального захисту населення в Україні : монографія. Умань : СПД Сочінський, 2016. 496 с.

Рецензент д.е.н., професор Вахович I.М. 